\title{
EFFECT OF IONOL EXTRACTION TEMPERATURE ONTO ITS GAS CHROMATOGRAPHIC DETECTION AT TRANSFORMER OIL
}

Introduction. Content of ionol antioxidant additive in the transformer oil (the oil) maintained within the normalized values limits enables preserving oils' operational properties and ensure reliable operation of oil-filled electrical equipment. The oil content in ionol may be assessed by gas chromatography (GC) method using the ionol isothermal liquid extraction with extractant and absolute calibration of the gas chromatograph with linear calibration curves. Provided the ionol distribution coefficient $K_{i}$ for the system "analyzed oil - ionol - extractant" differs from the distribution coefficient $K_{i}^{c}$ in the "calibration oil - ionol - extractant" system then GC assessment includes calculation using the single solvent extraction equation and the value of ionol distribution coefficient $K_{i}$ within equilibrated system "analyzed oil — ionol - extractant" followed by GC analysis of the extract containing ionol.

At that, to use a single solvent extraction equation, the analyzed oil distribution coefficient $K_{i}$ must be found experimentally beforehand [1,2]. When using ethanol as extractant within narrow extraction temperature interval from $t 1$ to $t 2$ the ionol concentration $C_{T M}$ in the oil is calculated by the formula

$$
C_{T M}=C_{e x t, t 1}\left(K_{i, t 1}+\frac{V_{e x t, t 1}}{V_{T M, t 1}}\right)=C_{e x t, t 2}\left(K_{i, t 2}+\frac{V_{e x t, t 2}}{V_{T M, t 2}}\right),
$$

where $C_{e x t, t 1}, C_{e x t, t 2}$ - ionol concentration at extracts;

$K_{i, t 1}, K_{i, t 2}$ - distribution coefficients;

$V_{T M, t 1}, V_{\text {ext } t 11}, V_{T M, t 2}, V_{\text {ext,t2 }}$ - oil and extractant volumes at respective extraction temperatures $t 1$ and $t 2$.

Analysis of recent researches and publications. It is known that the extraction temperature raise results in: changing the extractables' distribution coefficients in the "analyzed liquid — analyzed component - liquid extractant" system; improved GC sensitivity in detecting the analyzed component the liquid sample of analyzed substance; reduced duration of the analyzed component extraction procedure as compared, e.g. to the example room temperature [3]. At temperature level $t=20^{\circ} \mathrm{C}$ the duration $\tau$ of ionol extraction from oil using ethanol to reveal contents through GC is long enough: $\tau\left(20^{\circ} \mathrm{C}\right) \approx 2 \mathrm{~h}[2]$. While ionol extraction from oil using ethanol at elevated temperatures that can lead to increased ionol concentrations at the extract reducing the extraction process duration, that has a practical significance when oils GC analysis. Studying the effect of temperature changes in extractants-aided ionol extraction from oil on the distribution coefficients values $K_{i}$, and accordingly, on the result of ionol-in-oil presence assessment allows to set the desired temperature range establishing the ionol extraction optimum range of temperature control for the extracting device thermostating. In this connection studying the temperature effect on the ionol distribution coefficients $K_{i}$ at the "oil - ionol extractant" system within the extraction temperature range of $15 \ldots 75^{\circ} \mathrm{C}(288 \ldots 348 \mathrm{~K})$ is of practical importance when optimizing the conditions of ionol content GC-detection in oils.

Aim of the research is to study the temperature effect on the value of extraction degree and dis-

DOI 10.15276/opu.1.45.2015.16

(C) S.V. Zaitsev, 2015

ЕНЕРГЕТИКА. ТЕПЛОТЕХНІКА. ЕЛЕКТРОТЕХНІКА 
tribution coefficients for ionol in the "oil — ionol — ethanol" system in the ionol extraction temperature range of $15 \ldots 75{ }^{\circ} \mathrm{C}(288 \ldots 348 \mathrm{~K})$ for optimizing the conditions of $\mathrm{GC}$ implementation to determine ionol contents in the transformer oil by the method of ionol single extraction with ethanol and further calculation with estimated equation using the ionol distribution coefficient.

Main Body. The measurements are performed as described in [1] using petroleum oil of GK-type (ionol content $C_{T M}=0,30 \%$ mass fraction) and gas chromatograph with a thermal conductivity detector. Extractant agent: ethanol. The $N=V_{\text {ext }} / V_{T M}$ relation is equal to 0,2 or $1,0 . K_{i}$ value at a given temperature $t$ of ionol ethanolic extraction is calculated according to the formula

$$
K_{i}=C_{T M} / C_{e x t}-V_{e x t} / V_{T M} \text {. }
$$

The concentration value $C_{e x t}$, corresponding to the ionol chromatographic peak area $S_{\text {ext }}$ is found by linear calibration curves obtained through absolute calibration chromatography using calibration ionol ethanolic solutions. The distribution coefficients' $K_{i}$ dependencies upon extraction temperature are established within temperature range $15 \ldots 75^{\circ} \mathrm{C}$ (temperature control accuracy $\Delta t= \pm 0,5^{\circ} \mathrm{C}$ ) for each given value of fixed extraction temperatures. Reaching the phase equilibrium when ionol extraction under isothermal conditions at given temperatures $t$ is assessed studying the extracts concentration in ionol dependence upon ionol extraction duration of. The relative ionol extraction degrees $R_{i}, \%$, are calculated by the formula

$$
R_{i}=100\left(1+K_{i} \frac{V_{T M}}{V_{e x t}}\right)^{-1} .
$$

When ethanol densities $\rho_{\text {ext }}^{15}=0,806 \mathrm{~g} / \mathrm{cm}^{3}$ at $15{ }^{\circ} \mathrm{C}$ and $\rho_{\text {ext }}^{75}=0,740 \mathrm{~g} / \mathrm{cm}^{3}$ at $75^{\circ} \mathrm{C}$, as well as at oil densities $\rho_{T M}^{15}=0,890 \mathrm{~g} / \mathrm{cm}^{3}$ at $15{ }^{\circ} \mathrm{C}$ and $\rho_{T M}^{75}=0,850 \mathrm{~g} / \mathrm{cm}^{3}$ at $75{ }^{\circ} \mathrm{C}$, the difference between values $\alpha_{15}=\rho_{\text {ext }}^{15} / \rho_{T M}^{15}=0,91$ and $\alpha_{75}=\rho_{\text {ext }}^{75} / \rho_{T M}^{75}=0,87$ never exceed $4,4 \%$ relatively. That provides us possibility to apply formulae (1)...(3) without account of ionol extraction temperature influence onto $V_{\text {ext }} / V_{T M}$ or $V_{T M} / V_{\text {ext }}$ values.

The Table 1 exposes the relationship between temperature $t,{ }^{\circ} \mathrm{C}$ ionol distribution coefficients $K_{i}$, ionol concentration at extracts $C_{\text {ext }} \%$ mass fraction, relative ionol extraction degrees a $R_{i}$ at $N=0,2$ and $N=1,0$.

Table 1

Dependencies between temperature $t$ and the distribution coefficients $K_{i}$, ionol extraction grades $R_{i}$,

\begin{tabular}{|c|c|c|c|c|c|c|c|c|c|c|c|c|}
\hline$t$ & 15 & 18 & 20 & 22 & 26 & 32 & 40 & 45 & 55 & 65 & 75 & \multirow{2}{*}{$N$} \\
\hline$K_{i}$ & 2,95 & 2,70 & 2,50 & 2,39 & 2,12 & 1,77 & 1,52 & 1,38 & 1,25 & 1,16 & 1,10 & \\
\hline$R_{i}$ & 6,3 & 6,9 & 7,3 & 7,7 & 8,6 & 10,2 & 11,6 & 12,7 & 13,8 & 14,7 & 15,4 & \multirow{2}{*}{0,2} \\
\hline$C_{e x t}$ & 0,095 & 0,104 & 0,11 & 0,12 & 0,13 & 0,15 & 0,17 & 0,19 & 0,21 & 0,22 & 0,23 & \\
\hline$R_{i}$ & 25,3 & 27,0 & 28,2 & 29,5 & 32,1 & 36,1 & 39,7 & 42,0 & 44,4 & 46,3 & 47,6 & \multirow[b]{2}{*}{ 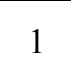 } \\
\hline$C_{e x t}$ & 0,076 & 0,081 & 0,085 & 0,089 & 0,096 & 0,108 & 0,119 & 0,126 & 0,133 & 0,139 & 0,143 & \\
\hline
\end{tabular}
ionol concentrations at extracts $C_{\text {ext }}$

From Table 1 we clearly observe that:

- the extraction temperature approaching to the ethanol boiling point $t_{b p}=78,37^{\circ} \mathrm{C}$ correlates with the distribution coefficient $K_{i}$ approaching to 1;

- when extraction temperature increase at $N=$ const the concurrent effects of $K_{i}$ value decrease, ionol extraction degree $R_{i}$ increase and ionol concentration at extract $C_{e x t}$ increase take place;

- under ionol extraction from oil isothermal conditions the extraction degree $R_{i}$ depends upon the distribution coefficient $K_{i}$ for ionol and volumes' ratio $N$, e.g. at $K_{i}=$ const the augmented $N$ increases the ionol extraction degree $R_{i}$ thus involving the resulting extract's ionol concentration lowering. 
The obtained $K_{i}=2,5$ at $t=20^{\circ} \mathrm{C}$ is fairly close to the mean value $K_{i}=2,2$ (relative divergence making 13,6\%), as the source [4] specifies. The dependency between distribution coefficients $K_{i}$ and the absolute temperature $T$ having shape of $K_{i}=f(T)$ can be represented with an equation used to describe the ideal solutions' extraction equilibrium [3]

$$
\ln K_{i}=A / T-B \text {. }
$$

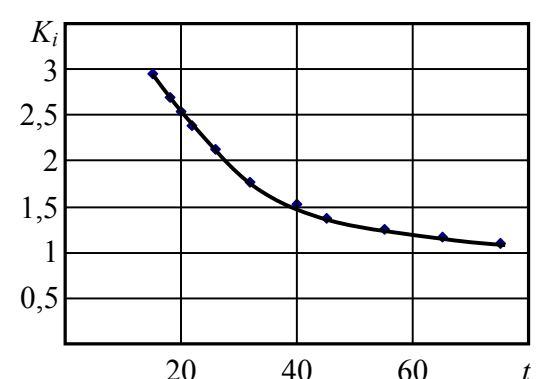

Fig. 1. Dependency between the distribution coefficients $K_{i}$ and temperature $t$

Fig. 1 represents the dependency between distribution coefficients $K_{i}$ and temperature values $t$.

The measurements' and calculations' results are given at the Table 2, including:

- $K_{i}^{\text {mean }}=0,5\left(K_{i}^{b}+K_{i}^{e}\right)$ - mean values of ionol distribution coefficient at $K_{i}^{b}$ (given the temperature $t_{b}$ at thermic range beginning) and $K_{i}^{e}$ (given the temperature $t_{e}$ at thermic range ending) within the given temperatures range;

$$
-\gamma_{t}=\Delta K_{i} / \Delta t_{R}-\text { mean thermic coefficient at }
$$
$\Delta K_{i}=K_{i}^{b}-K_{i}^{e}$ and $\Delta t_{R}=t_{e}-t_{b}$ within the given temperatures range;

$-\delta=100 \times \gamma_{t} / K_{i}^{\text {mean }}$ - relative change in $K_{i}$ coefficient at extraction temperature change by $1^{\circ} \mathrm{C}$ within the given extraction temperatures range;

$-\Delta t$ - recommended accuracy of ionol extraction temperature control when the relative deviation of distribution coefficient $K_{i}$ from the mean value $K_{i}^{\text {mean }}$ does not exceed $6 \%$ for the established temperature within the given ionol extraction temperatures range.

Table 2

Results obtained from measurements and calculations

\begin{tabular}{c|c|c|c|c|c|c|c|c}
\hline$T, \mathrm{~K}\left({ }^{\circ} \mathrm{C}\right)$ & $A$ & $B$ & $K_{i}^{\text {mean }}$ & $\Delta K_{i}$ & $\Delta t_{R},{ }^{\circ} \mathrm{C}$ & $\gamma_{t},\left({ }^{\circ} \mathrm{C}\right)^{-1}$ & $\delta, \%$ & $\Delta t,{ }^{\circ} \mathrm{C}$ \\
\hline $288 \ldots 305(15 \ldots 32)$ & 2650 & 8,12 & 2,36 & 1,18 & 17 & 0,0694 & 2,94 & \pm 1 \\
\hline $305 \ldots 313(32 \ldots 40)$ & 1626 & 4,76 & 1,65 & 0,25 & 8 & 0,0313 & 1,90 & \pm 2 \\
\hline $313 \ldots 348(40 \ldots 75)$ & 985 & 2,76 & 1,31 & 0,42 & 35 & 0,0120 & 0,92 & \pm 5 \\
\hline
\end{tabular}

Referring to the Table 2 we observe that there exist three temperature ranges for investigated oils $\left(\Delta t_{R 1}=15 \ldots 32{ }^{\circ} \mathrm{C}, \Delta t_{R 2}=32 \ldots 40^{\circ} \mathrm{C}, \Delta t_{R 3}=40 \ldots 75^{\circ} \mathrm{C}\right)$, where the coefficients " $A$ " and " $B$ " of equation (4) differ from the corresponding values for each of these temperature ranges. Since the oils operated at oil-immersed electric machinery have different physical and chemical properties, including the structural group composition (e.g., differences in content of aromatic hydrocarbons) affecting oil susceptibility to ionol, for each oil brand or different grades oils mixture coefficients " $A$ " and " $B$ " of the equation (4) are different. Under isothermal conditions, the extraction ratio " $A$ " in equation (4) represents the difference between the standard values chemical potentials for ionol in oil and in ethanol [3] and can be associated with the function

$$
A=f\left(Q_{T M}, Q_{\text {ext }}\right),
$$

where $Q_{T M}, Q_{e x t}$ - heat of ionol dissolution in oil and ethanol, respectively.

In the studied ionol extraction temperature range $\left(15 \ldots 75^{\circ} \mathrm{C}\right)$ the ionol melting range is $t_{m}=69,6 \ldots 70,0^{\circ} \mathrm{C}$ (ionol category " $A$ " as by TU38.5901237-90), indicating that the ionol dissolution in oil concurs to a thermal effect of dissolving the solid ionol in oil at $t<69,6^{\circ} \mathrm{C}$, dissolving the solid and liquid ionol mixture in the temperature range of $t=69,8 \ldots 70,0^{\circ} \mathrm{C}$, and dissolving the liquid ionol at $t>70,0{ }^{\circ} \mathrm{C}$. Considering that the ionol solubility in oil and ethanol under isothermal conditions is limited to respective saturated concentrations of ionol, the afore exposed can determine the presence of 
the specified temperature ranges $\Delta t_{R 1}, \Delta t_{R 2}, \Delta t_{R 3}$ being also characteristic when other liquid extractants, for example, 2-propanol, or acetonitrile, for which the evaporation temperature $t_{e v}$ is higher than the melting point $t_{m}$.

Results. The experimental series results showed that:

- Increasing the extraction temperature from $t=20$ to $75^{\circ} \mathrm{C}$ at optimum values $V_{T M}=50 \mathrm{~cm}^{3}$, $V_{\text {ext }}=10 \mathrm{~cm}^{3}, N=0,2$ gives rise to 2,1 times increase of extract content in ionol and to reduce the GC threshold value as to ionol oil content approx. about 2 times;

- At $t=65^{\circ} \mathrm{C}$ duration of ionol ethanolic extraction maxes approximately $\tau\left(65^{\circ} \mathrm{C}\right) \approx 55 \mathrm{~min}$, i.e. average 2-fold decreases comparing to $t=20^{\circ} \mathrm{C}$, that can be due to an increased rate of mass transfer in a heterogeneous extraction system "oil - ionol - ethanol";

- Temperature change in the range of $15 . . .32{ }^{\circ} \mathrm{C}$ results in a relative change in the distribution coefficient value $K_{i}$ no more than $\pm 40 \%$, so the ionol extraction in this temperature range is recommended to perform at $t=20^{\circ} \mathrm{C}$ and $\Delta t \leq \pm 1{ }^{\circ} \mathrm{C}$;

- Ionol extraction temperature change in the range of $32 \ldots 40{ }^{\circ} \mathrm{C}$ results in a relative change in the distribution coefficient value $K_{i}$ no more that $\pm 14,1 \%$, so the ionol extraction in this temperature range is recommended to perform at $t=36^{\circ} \mathrm{C}$ and $\Delta t \leq \pm 2{ }^{\circ} \mathrm{C}$;

- Ionol extraction temperature change in the range of $40 \ldots 75^{\circ} \mathrm{C}$ results in a relative change in the distribution coefficient value $K_{i}$ no more that $\pm 27,6 \%$, so the ionol extraction in this temperature range is recommended to perform at $t=65^{\circ} \mathrm{C}$ and $\Delta t \leq \pm 5^{\circ} \mathrm{C}$;

- When ionol concentration at oil makes $C_{T M} \geq 0,1 \mathrm{wt} \%$ the value $K_{i, t 2}$ for temperature $t 2$ when knowing the $K_{i, t 1}$ value for temperature $t 1$,can be calculated from the formula (1).

Conclusions. Based on the foregoing, when petroleum transformer oil ionol content determining with GC method at liquid ethanol use for ionol isothermal extraction:

- increasing the extraction temperature in the range $15 \ldots 75^{\circ} \mathrm{C}$ decreases the ionol distribution coefficients, increasing the oil-extracted ionol extraction degree and the extract ionolic concentration, reduces to extraction duration and the value of detection threshold as well as the overall length of transformer oil content in ionol detection procedure;

- recommended ionol extraction temperature range is $15 \ldots 32{ }^{\circ} \mathrm{C}$ at extraction temperature $20{ }^{\circ} \mathrm{C}$ with thermostatic precision $\Delta t \leq \pm 1{ }^{\circ} \mathrm{C}$, within range $32 \ldots 40{ }^{\circ} \mathrm{C}$ - at extraction temperature $36^{\circ} \mathrm{C}$ and $\Delta t \leq \pm 2{ }^{\circ} \mathrm{C}$, within range $40 \ldots 75^{\circ} \mathrm{C}$ - at extraction temperature $65^{\circ} \mathrm{C}$ and $\Delta t \leq \pm 5^{\circ} \mathrm{C}$.

\section{Література}

1. СОУ-Н ЕЕ 43.101:2009 Приймання, застосування та експлуатація трансформаторних масел. Норми оцінювання якості. — К.: КВІЦ, 2009. - 152 с.

2. Зайцев, С.В. Газохроматографическое определение коэффициентов распределения в системе "трансформаторное масло - ионол - экстрагент" / С.В. Зайцев, В.А. Кишневский, Б.А. Гуляенко // Пр. Одес. політехн. ун-ту. — 2013. — Вип. 3(42). — С. 86 — 90.

3. Зайцев, С.В. Методы определения коэффициентов распределения ионола в системе "трансформаторное масло - ионол - этиловый спирт". Выбор условий и процедур выполнения измерений / С.В. Зайцев, Д.А. Большаков, Г.К. Янковский // Электрические сети и системы. - 2011. № 5. - С. $48-56$.

4. СТО 56947007-29.180.010.008-2008 Методические указания по определению содержания ионола в трансформаторных маслах методом газовой хроматографии / ОАО ФСК ЕЭС, Россия. - М., 2008. $-15 \mathrm{c}$.

\section{References}

1. Ministry of Fuel and Energy of Ukraine (2009). Specification 43.101:2009 Acceptance, Application and Operation of Transformer Oils. Quality Assessment Standards [Pamphlet]. Kyiv: Ukrainian Research and Technology Association "AsElEnergo". 
2. Zaitsev, S.V., Kishnevsky, V.A. and Gouliaenko, A.B. (2013). Gas chromatographic determination of the distribution coefficients in the system "transformer oil — ionol — extractant". Odes 'kyi Politechnichnyi Universytet. Pratsi, 3, 86-90.

3. Zaitsev, S.V., Bol'shakov, D.A. and Yankovsky, G.K. (2011). Methods of definition of factors distributions ionol in system "transformer oil - ionol - ethyl alcohol". Choice of conditions and procedures of performance of measurements. Electric Networks and System, 5, 48-56.

4. Federal Grid Company of Unified Energy System (2008). Specification 56947007-29.180.010.008-2008 Methodological Guidelines on Determination of Ionol Content in Transformer Oils by Gas Chromatography [Pamphlet]. Moscow: OJSC VNIIE.

\section{АНОТАЦІЯ / АННОТАЦИЯ / ABSTRACT}

C.B. Зайцев. Вплив температури екстракції іонолу на його газохроматографічне визначення в трансформаторному маслі. Газохроматографічне визначення в трансформаторному маслі вмісту антиокислювальної присадки іонол сприяє забезпеченню надійної експлуатації маслонаповненого електричного обладнання. Робота присвячена вивченню впливу температури на значення ступенів екстракції і коефіцієнтів розподілу для іонолу в системі “масло іонол - етанол" при температурах екстракції $15 \ldots 75^{\circ} \mathrm{C}$. Дослідження виконано при оптимізації умов виконання газохроматографічного визначення вмісту іонолу в трансформаторному маслі методом екстракції іонолу етанолом і 3 використанням розрахункового рівняння для однократної екстракції. Встановлено, що підвищення температури екстракції іонолу в інтервалі $15 \ldots 75^{\circ} \mathrm{C}$ знижує значення коефіцієнтів розподілу для іонолу, збільшує значення ступеня екстракції іонолу і його концентрації в екстракті, зменшує тривалість екстракції, знижує числове значення порога визначення і загальну тривалість визначення змісту іонолу в трансформаторному маслі. Наведені рекомендації щодо інтервалу температур при виконанні екстракції іонолу.

Ключові слова: газова хроматографія, трансформаторне масло, іонол, коефіцієнт розподілу, екстракція, етанол, температура.

С.В. Зайцев. Влияние температуры экстракции ионола на его газохроматографическое определение в трансформаторном масле. Газохроматографическое определение в трансформаторном масле содержания антиокислительной присадки ионол способствует обеспечению надежной эксплуатации маслонаполненного электрического оборудования. Работа посвящена изучению влияния температуры на значения степеней экстракции и коэффициентов распределения для ионола в системе “масло - ионол - этанол” при температурах экстракции $15 \ldots 75^{\circ} \mathrm{C}$. Исследование проведено при оптимизации условий выполнения газохроматографического определения содержания ионола в трансформаторном масле методом экстракции ионола этанолом и с использованием расчетного уравнения для однократной экстракции. Установлено, что повышение температуры экстракции ионола в интервале $15 \ldots 75^{\circ} \mathrm{C}$ снижает значения коэффициентов распределений для ионола, увеличивает значения степени экстракции ионола и его концентрации в экстракте, уменьшает продолжительность экстракции, снижает числовое значение порога определения и общую продолжительность определения содержания ионола в трансформаторном масле. Приведены рекомендации относительно интервала температур при выполнении экстракции ионола.

Ключевые слова: газовая хроматография, трансформаторное масло, ионол, коэффициент распределения, экстракция, этанол, температура.

S.V. Zaitsev. Effect of ionol extraction temperature onto its gas chromatographic detection at transformer oil. The gas chromatography used for detecting antioxidizing additive ionol at transformer oil presence helps to ensure reliable operation of oil-filled electrical equipment. Changes in the ionol preliminary extraction temperature do affect the reliability of measurement result. This study aim consisted in investigating the temperature effect on the value of extraction degree and distribution coefficients for ionol in the system "oil — ionol — ethanol" at extraction temperatures $15 \ldots 75^{\circ} \mathrm{C}$. The experiment included optimization of gas chromatographic ionol in transformer oil detection conditions using method of ionol ethanol extraction and an estimated equation for a single extraction. Found is that the ionol extraction temperature increase in the range of $15 \ldots 75{ }^{\circ} \mathrm{C}$ reduces the values of the ionol distribution coefficients and increases the value of ionol extraction degree and its concentration in the extract reducing the extraction duration, lowering the value of the detection threshold and the total duration of ionol in transformer oil detection. The recommended values for ionol extraction in the temperature range of $15 \ldots 32{ }^{\circ} \mathrm{C}$ at a temperature of extraction $20^{\circ} \mathrm{C}$ with precision temperature $\Delta t \leq \pm 1{ }^{\circ} \mathrm{C}$, in the range of $32 \ldots 40^{\circ} \mathrm{C}$, with a temperature of extraction $36{ }^{\circ} \mathrm{C}$ and $\Delta t \leq \pm 2{ }^{\circ} \mathrm{C}$, in the range of $40 \ldots 75^{\circ} \mathrm{C}$, with a temperature of extraction $65^{\circ} \mathrm{C}$ and $\Delta t \leq \pm 5^{\circ} \mathrm{C}$.

Keywords: gas chromatography, transformer oil, ionol, distribution factor, extraction, ethanol, temperature. 